\title{
MONITORING OF CYSTICERCOSIS OF RABBITS IN FARMS OF DIFFERENT FORMS OF OWNERSHIP
}

\author{
Bogach M. V. ${ }^{1}$, Horobei O. O. ${ }^{2}$, Ivanchenko O. M. ${ }^{3}$, Vovk D. V. ${ }^{2}$ \\ ${ }^{1}$ Odesa Research Station of the National Scientific Center 'Institute of \\ Experimental and Clinical Veterinary Medicine', Odesa, Ukraine \\ ${ }^{2}$ National Scientific Center 'Institute of Experimental and Clinical \\ Veterinary Medicine', Kharkiv, Ukraine, e-mail: getready2010@ukr.net \\ ${ }^{3}$ Odesa State Agrarian University, Odesa, Ukraine
}

\begin{abstract}
Summary. The aim of the study was to determine the spread of pathogens of parasitic diseases in the digestive organs of rabbits in farms of various forms of ownership in Odesa Region. One thousand and two hundred rabbits of different age groups in specialized farms (which they use cage keeping of animals in compliance with all zoohygienic requirements and a balanced feeding ration), as well as 582 rabbits in private farms (which the type of feeding was mixed) were examined. Prevalence of parasitic infections of rabbits in specialized farms is $52.3 \%$, in household farms - $85.1 \%$. In specialized farms, prevalence of cysticercosis is $2.6 \%$ (with intensity of 3-7 cysticerci), eimeriosis - $14.0 \%$, trichostrongylosis - 13.6\%, and passalurosis - 20.6\%, two-component (eimeriosis + cysticercosis) infection $-1.0 \%$, three-component (eimeriosis + cysticercosis + passalurosis) infection $-0.5 \%$, total infestation (both mono- and mixed infections) with cysticerci - 4.1\%. In homestead farms, prevalence of cysticercosis is $27.7 \%$ (with intensity of 21-64 cysticerci), eimeriosis - 15.6\%, trichostrongylosis - 3.6\%, and passalurosis - 6.7\%, two-component (eimeriosis + cysticercosis) infection -24.2\%, three-component (eimeriosis + cysticercosis + passalurosis) infection $7.2 \%$, total infestation (both mono- and mixed infections) with cysticerci - 59.1\%. Cysticercosis is a common infection of rabbits in Odesa Region, which occurs often as part of mixed infections with pathogens eimeriosis and pasalurosis. The total infestation of rabbits with cysticerci in homestead farms was $55.0 \%$ higher than in specialized ones. Onecomponent infestations in specialized farms is $97.1 \%$ of sick rabbits, and in homestead farms - 63.0\%; two-component (eimeriosis + cysticercosis) infection $-1.9 \%$ and $28.5 \%$, respectively; and three-component (eimeriosis + cysticercosis + passalurosis) infection $-1.0 \%$ and $8.5 \%$, respectively
\end{abstract}

Keywords: pathogens, spread, Odesa Region, Ukraine, eimeriosis, passalurosis, trichostrongylosis

Introduction. Rabbits are prone to various diseases. Among the many pathogens, parasites play a major role in the emergence of a number of diseases in rabbits with increased morbidity and mortality, leading to economic losses. Some of the parasites are helminths, such as round worms, tapeworms and eimeria (Hajipour and Zavarshani, 2020; Bogach and Franchuk, 2018; Szkucik et al., 2014).

A significant number of reports, based on studies by both domestic and foreign authors, indicate that in the body of an animal of this species, several species of parasites can be localized simultaneously, which form a parasitocenosis (Yatusevich etal., 1990; Bogach and Trofimov, 2007; Strohlein and Christensen, 1983).

Along with protozoa, helminths and mites, various types of bacteria, viruses and fungi can be synchronously included in its composition (Youn, 2009).

The spread of the infestation depends on the age of the animals, the housing system, as well as the preventive and therapeutic measures used (Drouet-Viard and FortunLamothe, 2010; Kosenko et al., 2004; Jeklova et al., 2007; Pakandl et al., 2008).

Scientists have found that $41.6 \%$ of rabbits and $21.7 \%$ of hares are affected by pisiform cysticercosis. The intensity in rabbits ranges from 3 to 121, in hares - from
7 to 48 , and even up to 600 bubbles (Dubina, 2002; Duda et al., 2018; Melillo, 2007). In terms of industrial production, cysticercosis was registered in $4.27 \%$ of rabbits (Sołtysiak, Bednarski and Piekarska, 2007).

The study of parasitic fauna of rabbits in homestead and specialized farms is of current scientific and practical importance, as it allows for timely diagnosis and development of effective schemes for the treatment and prevention of mixed infections in rabbits.

The aim of the study was to determine the spread of pathogens of parasitic diseases in the digestive organs of rabbits in farms of various forms of ownership in Odesa Region.

Materials and methods. The material for the study were rabbits of different age groups, which belonged to specialized farms of LLC 'BBPROM' (Shemetove, Berezivka District), SG LLC 'Southern' (Ruskoivanivka, Bilhorod-Dnistrovskyi District), and PSP 'Druzhba' (Izmail District) in Odesa Region in which they use cage keeping of animals in compliance with all zoohygienic requirements and a balanced feeding ration (the main feeding ration was granulated feed), as well as private farms in Odesa, Berezivka, and Rozdilna districts of Odesa Region in which the type of feeding was mixed (hay, grain, and roots were additionally added to the granulated feed). 
The diagnosis was established taking into account epizootological data, clinical signs, laboratory tests and data of autopsy, which were performed in the Laboratory of Parasitology of the Odesa Research Station of the National Scientific Center 'Institute of Experimental and Clinical Veterinary Medicine' and in slaughterhouses of the enterprises.

To diagnose rabbit eimeriosis, the selected material (feces) was examined by Darling and Fülleborn method according to GOST 25383-82 (Gosstandart, 1982). The number of oocysts was counted under a small magnification microscope $(10 \times 10)$ in 20 fields of view, followed by calculation of the average. In order to determine the level of infestation with Passalurus ambiguus and Trichostrongylus instabilis, the feces of rabbits were examined by McMaster method for the presence and number of eggs of the pathogen. The level of spontaneous cysticercosis in rabbits was determined visually after slaughter and at autopsy by the number of bubbles on the internal organs.

The prevalence was determined by statistical processing. The intensity was determined by counting the number of helminth eggs and cysticerci in the implementation of incomplete helminthological autopsies of intestines of slaughtered rabbits according to Scrjabin (1928).
Results and discussions. In specialized farms, 1,200 rabbits were examined, of which 627 (52.3\%) animals were infested with parasitic pathogens. In household farms, 495 (85.1\%) from 582 examined rabbits were infected with parasites (Table 1).

According to the data of postmortem examination in specialized farms, cysticercosis of rabbits was registered in $31(2.6 \%)$ animals with intensity of 3-7 cysticerci. Eimeriosis was registered in 168 (14.0\%) animals, trichostrongylosis - in 163 (13.6\%), and passalurosis 247 (20.6\%). Two-component (eimeriosis + cysticercosis) infection was present in $1.0 \%$ of rabbits, three-component (eimeriosis + cysticercosis + passalurosis) infection - in $0.5 \%$. The total infestation (both mono- and mixed infections) of rabbits with cysticerci in specialized farms was $4.1 \%$ (Table 1 ).

In homestead farms, cysticercosis was registered in 161 (27.7\%) animals with intensity of 21-64 cysticerci. Eimeriosis was registered in 91 (15.6\%) animals, trichostrongylosis - in 21 (3.6\%), and passalurosis - 39 (6.7\%). Two-component (eimeriosis + cysticercosis) infection was present in $24.2 \%$ of rabbits, threecomponent (eimeriosis + cysticercosis + passalurosis) infection - in $7.2 \%$. The total infestation (both monoand mixed infections) of rabbits with cysticerci in homestead farms was $59.1 \%$ (Table 1).

Table 1 - Measures of parasitic diseases in digestive organs of rabbits in farms of various forms of ownership in the Odesa Region (according to the results of autopsies)

\begin{tabular}{|c|l|c|c|c|c|}
\hline $\begin{array}{c}\text { Farm type / feeding } \\
\text { type / total number } \\
\text { of examined rabbits }\end{array}$ & \multicolumn{1}{|c|}{ Disease / Pathogen } & $\begin{array}{c}\text { Disease } \\
\text { cases }\end{array}$ & $\begin{array}{c}\text { Prevalence, } \\
\%\end{array}$ & $\begin{array}{c}\text { Percentage } \\
\text { of cases, \% }\end{array}$ & $\begin{array}{c}\text { Intensity, } \\
\text { specimens }\end{array}$ \\
\hline \multirow{4}{*}{$\begin{array}{c}\text { Specialized / } \\
\text { granulated feed / } \\
1,200\end{array}$} & Eimeriosis / Eimeria spp. & 168 & 14.0 & 26.8 & $1,060.0 \pm 112.5^{*}$ \\
\cline { 2 - 6 } & $\begin{array}{l}\text { Trichostrongylosis / Trichostrongylus } \\
\text { instabilis }\end{array}$ & 163 & 13.6 & 26.0 & $11-13^{* *}$ \\
\cline { 2 - 6 } & Cysticercosis / Cysticercus pisiformis & 31 & 2.6 & 4.9 & $3-7^{* * *}$ \\
\cline { 2 - 6 } & Eimeriosis + Cysticercosis & 12 & 1.0 & 1.9 & - \\
\cline { 2 - 6 } & Eimeriosis + Cysticercosis + Passalurosis & 6 & 0.5 & 1.0 & - \\
\cline { 2 - 6 } & Total & 627 & 52.3 & 100 & - \\
\hline \multirow{3}{*}{$\begin{array}{c}\text { Household / } \\
\text { mixed feed / }\end{array}$} & Eimeriosis / Eimeria spp. & 91 & 15.6 & 18.4 & $1,210.0 \pm 105.2^{\star}$ \\
\cline { 2 - 6 } 582 & Passalurosis / Passalurus ambiguus & 39 & 6.7 & 7.9 & $35-111^{* *}$ \\
\cline { 2 - 6 } & $\begin{array}{l}\text { Trichostrongylosis / Trichostrongylus } \\
\text { instabilis }\end{array}$ & 21 & 3.6 & 4.2 & $21-35^{* *}$ \\
\cline { 2 - 6 } & Cysticercosis / Cysticercus pisiformis & 161 & 27.7 & 32.5 & $21-64^{* * *}$ \\
\cline { 2 - 6 } & Eimeriosis + Cysticercosis & 141 & 24.2 & 28.5 & - \\
\cline { 2 - 6 } & Eimeriosis + Cysticercosis + Passalurosis & 42 & 7.2 & 8.5 & - \\
\cline { 2 - 6 } & Total & 495 & 85.1 & 100 & - \\
\hline
\end{tabular}

Notes: ${ }^{\star}$ - number of oocysts in $1 \mathrm{~g}$ of feces; ${ }^{\star *}$ - number of helminths in the intestinal cavity; ${ }^{\star *}$ — number of cysticerci on the mesentery and omentum.

The total infestation of rabbits with cysticerci in homestead farms was $55.0 \%$ higher than in specialized ones.
One-component infestations in specialized farms were registered in $97.1 \%$ of sick rabbits, and in homestead farms - in 63.0\%; two-component (eimeriosis + 
cysticercosis) infection was present in $1.9 \%$ and $28.5 \%$, respectively; and three-component (eimeriosis + cysticercosis + passalurosis) infection - in $1.0 \%$ and $8.5 \%$, respectively (Figs. 1-2).

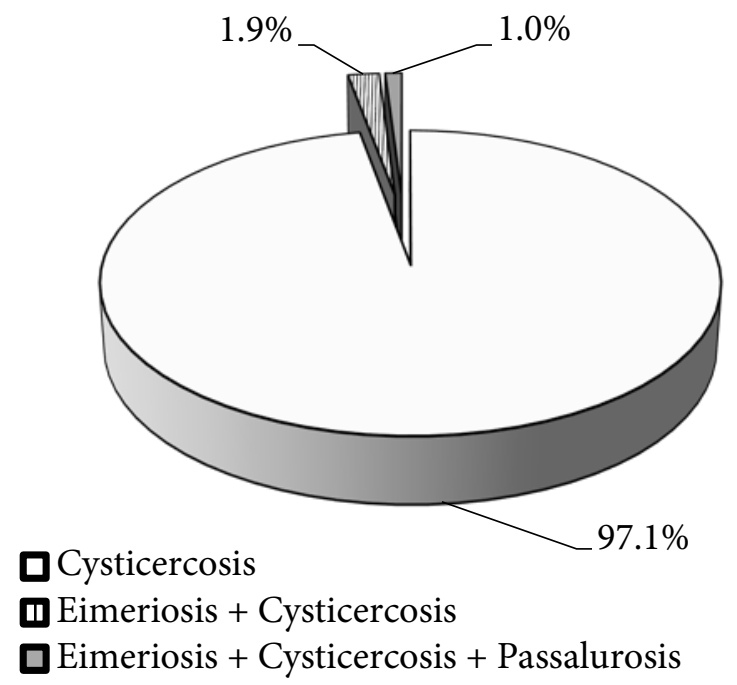

Figure 1. Mono- and mixed infections of rabbits in specialized farms

Conclusions. 1. Prevalence of parasitic infections of rabbits in specialized farms in Odesa Region is $52.3 \%$, in household farms $-85.1 \%$.

2. In specialized farms, prevalence of cysticercosis is $2.6 \%$ (with intensity of 3-7 cysticerci), eimeriosis $14.0 \%$, trichostrongylosis $-13.6 \%$, and passalurosis 20.6\%, two-component (eimeriosis + cysticercosis) infection $-1.0 \%$, three-component (eimeriosis + cysticercosis + passalurosis) infection $-0.5 \%$, total infestation (both mono- and mixed infections) with cysticerci $-4.1 \%$.

3. In homestead farms, prevalence of cysticercosis is $27.7 \%$ (with intensity of 21-64 cysticerci), eimeriosis $15.6 \%$, trichostrongylosis - $3.6 \%$, and passalurosis $6.7 \%$, two-component (eimeriosis + cysticercosis)
Thus, cysticercosis is a common infection of rabbits in Odesa Region, which occurs often as part of mixed infections with pathogens eimeriosis and pasalurosis.

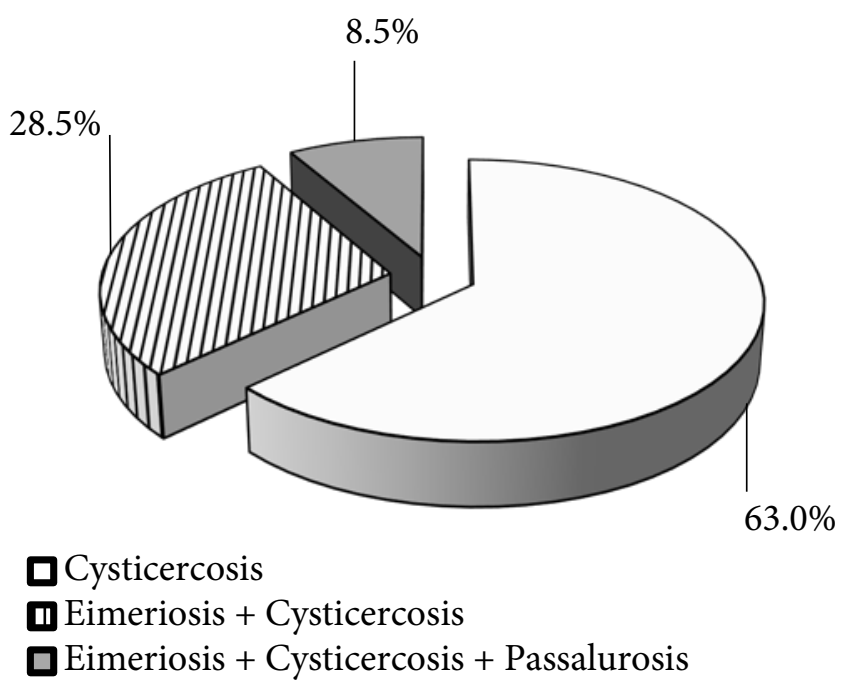

Figure 2. Mono- and mixed infections of rabbits in homestead farms

infection $-24.2 \%, \quad$ three-component (eimeriosis + cysticercosis + passalurosis) infection - 7.2\%, total infestation (both mono- and mixed infections) with cysticerci $-59.1 \%$.

4. Cysticercosis is a common infection of rabbits in Odesa Region, which occurs often as part of mixed infections with pathogens eimeriosis and pasalurosis. The total infestation of rabbits with cysticerci in homestead farms was $55.0 \%$ higher than in specialized ones. Onecomponent infestations in specialized farms is $97.1 \%$ of sick rabbits, and in homestead farms - 63.0\%; twocomponent (eimeriosis + cysticercosis) infection $-1.9 \%$ and 28.5\%, respectively; and three-component (eimeriosis + cysticercosis + passalurosis) infection $1.0 \%$ and $8.5 \%$, respectively.

\section{References}

Bogach, M. V. and Franchuk, L. O. (2018) 'The effect of Eimeria on the body of rabbits during parasitism' [Vplyv eimerii na orhanizm kroliv za parazytonosiistva], Actual Problems of Veterinary Biotechnology and Infectious Pathology of Animals: materials of the annual scientific and practic conference of young scientists, Kyiv, 19 July 2018 [Aktualni problemy veterynarnoi biotekhnolohii ta infektsiinoi patolohii tvaryn: materialy shchorichnoi naukovo-praktychnoi konferentsii molodykh vchenykh, Kyiv, 19 lypnia 2018 r.]. Kyiv: Komprynt, pp. 21-22. Available at: http://ivm.kiev.ua/wp-content/uploads/Конферен ція-молодих-учених-2018-Програма.pdf. [in Ukrainian].

Bogach, M. V. and Trofimov, M. M. (2007) 'Invasive diseases of the digestive system of rabbits in the farms of Odesa Region' [Invaziini khvoroby systemy travlennia kroliv $\mathrm{v}$ hospodarsvakh Odeskoi oblasti], Agrarian Bulletin of the Black
Sea Littoral [Ahrarnyi visnyk Prychornomoria], 39, pp. 96-99. [in Ukrainian].

Drouet-Viard, F. and Fortun-Lamothe, L. (2010) 'Review: I - The organisation and functioning of the immune system: Particular features of the rabbit', World Rabbit Science, 10(1), pp. 15-23. doi: 10.4995/wrs.2002.472.

Dubina, I. N. (2002) Cysticercosis pisiformis of rabbits (epizootology, pathogenesis, symptomatology and control measures) [Tsistitserkoz piziformnyy krolikov (epizootologiya, patogenez, simptomatika $i$ mery bor'by)]. The dissertation thesis for the scientific degree of the candidate of veterinary sciences. Vitebsk: Belarusian Scientific Research Institute of Experimental Veterinary named after S. N. Vyshelesskiy. Available at: https:// rusneb.ru/catalog/000200_000018_RU_NLR_bibl_446463. [in Russian]. 
Duda, Y. V., Prus, M. P., Kuneva, L. V. and Shevchik, R. S. (2018) 'The effect of Cysticercosis invasion on the internal organs condition and meat productivity of rabbits' [Vplyv tsystytserkoznoi invazii na stan vnutrishnikh orhaniv i miasnu produktyvnist kroliv], Veterinary Biotechnology [Veterynarna biotekhnolohiia], 33, pp. 31-38. doi: 10.31073/vet_biotech33-04. [in Ukrainian].

Gosstandart (The USSR State Committee of Standards) (1982) GOST 25383-82. Domestic Animals. Methods of Laboratory Diagnostics of Coccidiosis [Zhivotnye sel'skokhozyaystvennye. Metody laboratornoy diagnostiki koktsidioza]. Moscow: Izdatel'stvo standartov. [in Russian].

Hajipour, N. and Zavarshani, M. (2020) 'Ectoparasites and endoparasites of New Zealand white rabbits from North West of Iran', Iranian Journal of Parasitology, 15(2), pp. 266-271. doi: 10.18502/ijpa.v15i2.3310.

Jeklova, E., Leva, L., Kudlackova, H. and Faldyna, M. (2007) 'Functional development of immune response in rabbits', Veterinary Immunology and Immunopathology, 118(3-4), pp. 221-228. doi: 10.1016/j.vetimm.2007.05.003.

Kosenko, M. V., Kotsiumbas, I. Ya., Kosenko, Yu. M., Datskiv, O. M. and Lisova, N. E. (2004) 'Control of the influence of veterinary medicines on the state of animals' immunity' [Kontrol vplyvu veterynarnykh likarskykh zasobiv na stan imunitetu tvaryn], Veterinary Medicine of Ukraine [Veterynarna medytsyna Ukrainy], 1, pp. 43-44. [in Ukrainian].

Melillo, A. (2007) 'Rabbit clinical pathology', Journal of Exotic Pet Medicine, 16(3), pp. 135-145. doi: 10.1053/j.jepm. 2007.06.002.

Pakandl, M., Hlásková, L., Poplštein, M., Chromá, V., Vodička, T., Salát, J. and Mucksová, J. (2008) 'Dependence of the immune response to Coccidiosis on the age of rabbit suckling', Parasitology Research, 103(6), pp. 1265-1271. doi: 10.1007/ s00436-008-1123-0.
Skrjabin, K. I. (1928) Method of Complete Helminthological Autopsies of Vertebrates, Including Humans [Metod polnykh gel'mintologicheskikh vskrytiy pozvonochnykh, vklyuchaya cheloveka]. Moscow: Moscow State University. [in Russian].

Sołtysiak, Z., Bednarski, M. and Piekarska, J. (2007) 'Cysticercosis pisiformis in rabbit livers' [Wągrzyca wątroby królika], Medycyna Weterynaryjna, 63(10), pp. 1255-1257. Available at: http://www.medycynawet.edu.pl/images/stories/ pdf/pdf2007/102007/200710s12551257.pdf. [in Polish].

Strohlein, D. A. and Christensen, B. M. (1983) 'Metazoan parasites of the eastern cottontail rabbit in western Kentucky', Journal of Wildlife Diseases, 19(1), pp. 20-23. doi: 10.7589/00903558-19.1.20.

Szkucik, K., Pyz-Łukasik, R., Szczepaniak, K. O. and Paszkiewicz, W. (2014) 'Occurrence of gastrointestinal parasites in slaughter rabbits', Parasitology Research, 113(1), pp. 59-64. doi: 10.1007/s00436-013-3625-7.

Yatusevich, A. I., Medvedskaya, T. V., Gerasimchik, V. A. and Zabud'ko, V. A. (1990) 'Eimeriid fauna of fur-bearing animals and rabbits' [Fauna eymeriid pushnykh zverey i krolikov], Prevention and Control Measures Against Diseases of Young Farm Animals: abstracts of the republican scientific and industrial conference, Vitebsk, 12-13 September 1990 [Profilaktika $i$ mery bor'by $s$ boleznyami molodnyaka sel'skokhozyaystvennykh zhivotnykh: tezisy dokladov respublikanskoy nauchno-proizvodstvennoy konferentsii, Vitebsk, 12-13 sentyabrya 1990 g.]. Vitebsk, pp. 186-187. [in Russian].

Youn, H. (2009) 'Review of zoonotic parasites in medical and veterinary fields in the Republic of Korea', The Korean Journal of Parasitology, 47(Suppl), pp. S133-S141. doi: 10.3347/kjp.2009. 47.S.S133. 